\title{
DESENVOLVIMENTO DE TECNOLOGIA PARA PRODUÇÃO DE ÓLEOS VEGETAIS COMO ESTRATÉGIA DE FORTALECIMENTO DA AGRICULTURA FAMILIAR NA REGIÃO DE MARABÁ - PARÁ
}

\author{
Daise Silva Ferreira $^{1}$; Fernando Michelotti ${ }^{2}$ \\ ${ }^{1}$ Discente do curso de Agronomia, Faculdade de Ciências Agrárias de Marabá (FCAM), Universidade Federal do Pará \\ (UFPA), Marabá, Pará. E-mail: daise19@ hotmail.com. \\ ${ }^{2}$ Prof., M.Sc., FCAM, UFPA, E-mail: fmichelotti@ufpa.br.
}

RESUMO: A preservação dos ecossistemas naturais tem sido debatida nos diversos setores da sociedade, bem como a fixação dos agricultores no campo. Neste novo cenário regional, o projeto propõe contribuir no processo de consolidação e fortalecimento das Cooperativas Municipais de Produção Familiar no Território do Sudeste Paraense. Deste objetivo geral surgem linhas de pesquisas, nas quais se insere a proposta de identificação do potencial de comercialização de óleos vegetais no mercado regional. Será realizado um levantamento da capacidade produtiva de frutos, sementes e óleos vegetais das espécies: andiroba, babaçu, cacau, cupuaçu e maracujá da agricultura familiar bem como a identificação, descrição e análise de experiências de produção artesanal e industrial e comercialização desses óleos nos municípios do Território do Sudeste Paraense junto a feiras livres, comércio varejista, farmácia de manipulação e comércio atacadista, que resultará numa projeção da demanda potencial para ampliação dessa comercialização, a identificação de preferências e exigências dos compradores em relação à quantidade e qualidade dos produtos, bem como os preços pagos ao produtor, as margens de lucro e mecanismos de apropriação dos diferentes agentes mercantis. Também será realizado levantamento da produção de frutas, sementes e óleos vegetais pelo segmento da agricultura familiar, tanto oriundas de atividade extrativista, como de atividade agrícola. Os levantamentos de campo serão feitos a partir de entrevistas estruturadas, aplicadas em feiras para zoneamento de produtores e fornecedores de óleos no mercado regional. Diante do desmatamento e a implantação de pastagens, que reduz a biodiversidade e altera o quadro de equilíbrio ambiental, a atividade extrativista pode contribuir para a redução do abandono das propriedades, visto que contribui para a conservação de matas nativas e gera renda, Espera-se ainda demonstrar a importância de atividades produtivas que promovam a conservação dos ecossistemas naturais, através do uso de produtos oriundos do extrativismo, apontando como a produção de óleos vegetais pode contribuir para melhorar a renda das famílias assentadas. Explicar como se dá a organização da comercialização regional, descrevendo como os atores se interligam e conectam-se nas diversas redes de ações, visto que a Região Amazônica constitui-se em um dos mais diversificados biomas do planeta, tendo espécies florestais nativas com grande potencial de exploração racional e vasto conhecimento de populações locais na utilização destes bens, que associados às políticas de incentivo ao desenvolvimento sustentável e a crescente busca por óleos pelas indústrias de cosméticos, fitofarmacêutica e alimentar, tem ganhado força e está em ascensão. Por se tratar de um projeto em andamento, alguns resultados já foram encontrados, quais sejam: i) - as comercializações são feitas em feiras; ii) o mercado é informal sem garantia de qualidade, porém com boa aceitação pelo mercado consumidor; iii) - os principais óleos são de andiroba, de cupuaçu e de babaçu. Iniciaram-se trabalhos com o desenvolvimento de técnicas para a extração de óleos de andiroba e babaçu. A Federação das Cooperativas do Sul do Pará (FECAT) está trabalhando com o processo de beneficiamento das sementes do cupuaçu, com a fermentação, torração e extração do óleo, além de realizar análises químicas para o controle de qualidade.

PALAVRAS-CHAVE: Comercialização, oportunidades, extrativismo, preservação ambiental. 